\title{
James Bay Crees' Life Projects and Politics: Histories of Place, Animal Partners and Enduring Relationships
}

\author{
HARVEY A. FEIT
}

\section{Contradictions?}

In 1994, Matthew Coon Come, who was then Grand Chief of the Grand Council of the Crees in Quebec, appeared before a committee of the Massachusetts Legislature to ask them to support the Cree struggle against the proposed Great Whale hydroelectric project by not buying HydroQuebec power. The Grand Council of the Crees had just signed a complementary agreement with Hydro-Quebec, the public electricity utility of the province, giving $\mathrm{C} \$ 50$ million to the Crees and allowing new construction at the site of a hydroelectric dam that was part of the LaGrande project, which had been constructed over the previous two decades. A committee member asked:

Why would you be so agreeable and so willing to modify an agreement, in light of the fact that we have heard that you folks signed the original agreement in I975 under duress? In other words, if I were you, and Hydro-Quebec came to me and said, 'by the way ... we want to [install] four more sub-stations', I would be telling Hydro-Quebec to take a hike. (in Isacsson I996)

The Grand Chief explained that 'we live in a society in which we have to see how we can coexist, how we can live together [with Quebec].' His questioner persisted, asking the Cree if it was true Hydro-Quebec needed Cree approval to undertake the construction. Grand Chief Coon Come confirmed that and explained that the Cree agreed to more construction in part because of the already compromised quality of these areas - the 'river ... is already dead'. But there was no escaping the implication that had been painted by the questioner: the Crees were not really interested in saving the rivers, animals and a hunting way of life, but in money. 
This was a trap the Cree political leaders had clearly foreseen, and there were strong disagreements among them about whether to sign another in a series of agreements that made concessions to Hydro-Quebec, while fighting new project plans (in Isacsson 1996). The Cree participants in that debate had several reasons for signing, but they did not think that their actions were inconsistent, or opportunist. What they all were concerned about was that non-Crees would not understand the choices they were making, and thus they would be vulnerable to having the new agreement used against them. The differences among Cree leaders were over whether to take the risks. The Crees have been accused of similar contradictions repeatedly by the media and non-Crees, by governments and developers, and by their allies and social analysts (see LaRusic et al. 1979; Feit 1985, 2004; Tanner 1999).

It is assumed by most analysts that the Cree organizations would, if they could, simply oppose large-scale development projects on their lands. This appears to make sense because these are projects which many Crees insist have detrimental effects on their lives and the lands they occupy, and the great majority of Cree leaders and people are unwilling to accept deals that give them cash for accepting destruction. Yet they have signed a series of agreements with Hydro-Quebec and Quebec that provide funds to improve Cree lives and communities and permit development projects, albeit mostly of modest scale. That most Crees do not see contradictions in the political actions the leaders pursue, even where their opponents, their supporters and social analysts do, suggests that Crees' agency does not arise solely as a response to development projects or from agreements that offer cash, but from a different setting. I will explore their actions as rooted not in opposition or opportunism, but in the practice of everyday life in communities and on the land.

\section{Life Projects: Places, Histories and Animals}

In James Bay Cree struggles against transnational hydroelectric and forestry developments Cree leaders address state institutions; forge access to transnational forums; build alliances with other Indigenous, environmental and human rights movements; and build relationships with international media and access to world financial centres (see Coon Come and Craik, chapters 9 and $\mathrm{IO}$ in this volume; Rousseau 200I).

Yet James Bay Cree leaders also draw on powerful paradigms for collective agency provided by Cree hunters and hunting leaders. ${ }^{2}$ The hunters embody practices and envision desired ways of living in the context of hunting on a land they know intimately. These hunting leaders typically live for half or more of the year on the particular tracts of land that they have inherited, used and stewarded over their lifetimes, and these tracts are places they have nurtured and made into their homes. 
The processes of place-making (Gupta and Ferguson 1999) are accomplished not only through the actions of those on the land but also through their long histories of connections to markets and governments. As a result, their landscapes and their agency are not isolated or separate from the contexts that inform the struggles that Cree political leaders undertake; indeed, they are closely connected, as I will show. While many outside observers see Cree hunters as tied to the land in ways that isolate them from national politics and transnational markets, the experiences and lessons of hunting leaders are easily related and relevant to the decisions of Cree political leaders. This chapter develops an account of Cree agency in which I stress Cree statements, and my own understandings, of Cree hunters' life project politics. It is a case study for the analysis of Indigenous practices that are rooted in life projects closely linked to local places but that have wide connections to other places and broad political relevance. ${ }^{3}$

Cree hunters' lives and problems are place-based not universalist because they are concerned with communities and lands that are the intimate settings of their everyday lives. In a sense, they live in a world in which their communities and lands are centres, not the margins of some other cosmopolitanized place. ${ }^{4}$ Yet they are connected widely. Cree hunters' communities and hunting lands are places where they encounter people from transnational corporations, trading empires, government agencies, diverse political ideologies, and international legal forums. Their lands and communities are also places to which they invite representatives from other communities to build understanding and connections (see, for example, Craik and McRae, chapters Io and 7 in this volume).

Histories are part of both hunting and the processes of landscape making. Indeed, the land is layered with histories both personal and far-reaching. Place names known to and used by hunters who live on a particular hunting territory over many years cover nearly every feature of the landscape, and many are tied to stories of how the name came to be given - stories that recall past persons, events and associations. They also record past ties to Europe through the fur trade, as at 'Dress-up Creek', where hunters prepared to descend the last stretch of the Rupert river to enter the fur-trade post and meet the European traders. The presence of other Indigenous peoples is recorded, for example, by the Cree places named for Iroquois, or Haudenosaunee, who raided the area in the late seventeenth century by travelling along particular rivers that now carry their Cree names. Connections to Canada and the United States occur through the names of the first places where an early American sport hunter, known in Cree as a 'long-knife', did something memorable. They record corporate connections and histories of commercial fisheries, mines, sawmills and trading posts, now closed. 
These localized histories are manifested as interrelated places, stories that are associated with particular Cree predecessors, personal memories and ongoing practices of occupying the land and of hunting. These intersections of places, histories, persons and activities tie the hunters to distant parts of the world and to the people who have come from those parts and entered into relationships here. They record the encounters that give hunters knowledge, experience and relationships to those other places, times and people that are rooted in their hunting places and in their own sense of identity. And they can draw on long and rich encounters with some of these others. Hunters are connected far and they have often been connected for long. But they are not connected universally. Their places, histories and relationships are always personal and specific, even as they are generalizable.

These hunters' relationships extend beyond the human world to the worlds of animals and other non-human beings that are part of the multiperson process of the hunt. Animals are hunted and are encountered as partners in the hunt, as I will indicate below. Animals are partners not only in the chase, but in the histories they produce, and they too are recorded and present in the place names that recall memorable encounters. They are also parts of the relationships that tie these places through time to other places far away, for they too are part of the fur trade, and they too are partners in the suffering that results from development projects.

When people come from other places they enter, whether they know it or not, Cree places in which their presence sets them into arenas of Cree life projects. To encounter these places, histories and relationships is to enter into new/old relationships not solely determined by the conditions and needs of the arrivees, even if they are unaware of the specificities of these places.

For example, the Crees as a nation have signed a treaty that governments consider to have significantly constrained Cree sovereignty over lands, although the legal reality is somewhat more complex because specific provisions of the agreement recognize Cree systems of territoriality and governance (the James Bay and Northern Quebec Agreement (JBNQA), I975, between the Crees, Inuit of northern Quebec, Canada, Hydro-Quebec and the James Bay Development and Energy Corporations). The inequalities between Cree and governments profoundly shape how Crees and governments act on the land, and the very unequal consequences their actions have for the other. Therefore recognition of Cree tenure is clearly thought to be quite minimal by governments, both because they refuse to take them into full consideration, and because they consider the Cree hunting territories as isolated and exclusively involved with the Crees, not as places with far-reaching connections, recognitions and histories. ${ }^{5}$ Whether governments ever recognize these dimensions of their obligations as such, or not, they constantly are engaged with them for there is no general Cree acquiescence to the unique sovereignty 
claimed by the governments of Canada and Quebec. Autonomy that does not recognize exclusive sovereignty is exercised every day by Cree hunters on the land they care for and nurture (see below). The contests over the imposition of more and more constraints by governments go on day by day, intrusion by intrusion, hunting territory by hunting territory, without Cree consent. Cree people's agency has its fullest expression in these very personal and yet shared practices of exercising an inherent ownership and governance of land, in the broadest sense. This exercise is embedded in Cree life projects.

\section{Hunters' Life Projects in the Face of Development}

The recent affidavits given by hunting leaders as part of their testimony for a court case against forestry companies articulate clearly the everyday problems the hunters face, the relationships out of which their actions emerge, and their assumption and exercise of inherent responsibility for the whole land. The series of court cases against the governments of Quebec and Canada and over twenty logging companies sought to get the courts to regulate forestry cutting because of the failure of governments to fulfil their obligations under the JBNQA to regulate forestry activities on Cree territories and to provide an effective voice for Crees in forestry management. Many Crees also emphasized that the companies, with government authorization, were accelerating forestry cutting and their destructive effects on forests, lands, wildlife and the Crees.

Allen Saganash, Sr. of Waswanipi, whose hunting lands had not yet been cut, described his inherent responsibilities of governance, as well as what he wanted to protect as a hunting territory leader, and on what he did and did not want to compromise. ${ }^{6}$

I am the Ndoho Ouchimau [hunting leader] of trapline WosA [a governmentinitiated designation for hunting territories, see below]. I am 80 years old this year....

As I said our land is uncut now but I know Donahue [a forestry corporation] plans to build a road into it.... This will seriously affect my hunting grounds.

We had a consultation session with Donahue... The idea was to try to protect some wildlife habitat....

I am opposed to this road. Ours is good hunting and fishing land. The food is very good quality. The road will change all that; it will damage the habitat and open it up to hunters and fishermen....

I want all of this considered in a full environmental assessment but they won't do it. I know the government well. I have seen how they work throughout my life. They refuse to consider all development together. I have no chance to get all these issues looked at. I worry all the time about what will happen when the 
road comes. The road is not to come to the heart of my land. I don't want it. The government is not trustworthy...

We are pushed out of our land again and again. We are told to move our hunting grounds. I have seen this happen many times in Waswanipi.

They concentrate the cutting too heavily in one place. Too much is cut. There are too many roads.

Others support me on this....

The companies and the government don't listen to us. They take what is ours and push us aside. This must stop. (Affidavit of Allen Saganash, Sr, 22 July I999)

Allen Saganash eloquently expresses his rights as Ndoho Ouchimau to a decisive say in what happens on his lands, his sense of loss and fear of destruction, and his experiences of government and corporate betrayals, domination, and failures both to protect the land and to respect the Crees. He implies that the Crees have shared the land enough.

Joseph Neeposh, an elderly hunting leader, indicated that he has shared because he recognized the needs of others, that he expected them to consider his needs in turn, but that continued sharing might not be appropriate under all circumstances.

I am the Ndoho Ouchimau or tallyman of the Ndoho Istchee or trapline now known as $\mathrm{W}-\mathrm{IO}$....

Everyone in our community understands my authority and respects it. They know that I am the one that decides who can have access to the land and where they can hunt, fish or trap. They know that I must guide people to productive areas while I protect the land and the animals from overuse. Non-Natives and the logging companies do not understand or respect my role. They come to the land without my permission and take what they want.

All these roads, camps and activities lead me to believe that my Ndoho Istchee will soon be even more affected by forestry. I do not want this to happen. I want the game to stay....

I honestly think it is time for the cutting to stop in my hunting territory.

I understand that the forestry workers presently working in my hunting territory need their work for their families. If they wish to continue with forestry operations, they may do so. But they must consider my livelihood. The land is where I work and support myself. The forestry companies and those responsible for the cutting must do something to help me continue to live on my trapline. I do not want my Ndoho Istchee to be like some of the other Waswanipi traplines. I know they could eventually destroy it. I do not want to move ... to another hunting territory. It would be an expropriation of my hunting territory where I have hunted all my life. (Affidavit, Joseph Neeposh, 22 July I999)

These testimonies echo the common themes of rights, destruction, betrayal, the need for restrictions on forest cutting, and a common call for respectful sharing. Throughout these affidavits Cree hunters eloquently reveal the sovereignty the Cree hunters still exercise, and their continuing determination 
to bring changes to the present relationships with governments and companies. These views have been repeatedly misunderstood by supporters of Cree struggles. The hunters assert basic and unchallengeable rights to their lands, yet they also express a willingness to respect the needs of others and an expectation that this will be reciprocated. As their assertions of ongoing governance of their lands indicate, this is not a compromise that arises out of subordination or a politics of the oppressed. It is a vision that arises out of the tie to the land and to all that has occurred on the land. It is embedded in the changing historical relationships of this place, as well as in their intimate relationships with the land and animals.

\section{Histories of Relationships}

\section{The fur trade: commerce, relationships and reciprocities}

The recent Cree histories of the abuse of lands and of ignoring the Cree that these affidavits express also allude to older histories of relationships, relationships that endured for decades and even centuries.

Cree stories of the fur trade have been reported in the recent literature (see Scott 1989; Feit 1994), but here I want to note the recent work by ethno-historians on the fur trade that echoes many of the Cree stories. The trade had begun in the James Bay area by the I670s, and both Cree stories and recent research reveal rich and complex histories of alliances, partnerships and reciprocities in a trade in which the fur traders' practices were often adapted to Cree social values. There is not one fur trade but many (Francis and Morantz 1983). Here I will pick out some threads relevant to the newly realized aspects of much, but not all, of this trade.

The fur trade in the James Bay region was without doubt a very profitable and capital-making enterprise par excellence throughout almost all of its three centuries. Capital was accumulated as a result of substantial profits, mainly by the London-based Hudson's Bay Company ( $\mathrm{HBC}$ ), but also during several periods by Montreal traders. The trade produced exceptional profits in part because it exchanged generally easy-to-produce European goods with hunters, who welcomed them but had access to them only through traders. In exchange, furs and, until the mid-nineteenth century, especially beaver pelts were in high demand as valuable goods in Europe. From a Cree perspective, furs were labour intensive to produce, but many fur-bearers were also food staples, and trading their skins was not an inappropriately high labour cost over and above a subsistence hunting effort. A key feature of the profitability of the trade to Europeans was that it depended on Cree production on the land using Cree social and economic organization. It 
was to the advantage of $\mathrm{HBC}$ profitability to encourage Crees to produce furs because they provided most of their own subsistence needs, something European trappers would not do were the $\mathrm{HBC}$ to change its strategies and employ such production methods (Tanner 1979). In the twentieth century, with an increasing government presence, it was also in the interests of the $\mathrm{HBC}$ to promote exclusive Cree occupation and tenure of land as a barrier against itinerant trappers financed by competing non-resident traders.

From the Cree perspective the trade was beneficial for the increased security and labour-saving devices it brought, and although the Crees became dependent on the trade for these goods, their needs were specific and limited within a Cree economy of reciprocity (Scott 1983). The traders' records are replete with the difficulties of getting Crees to trap more than was required to secure their equipment and supply necessities and specific 'luxuries' (Salisbury 1976). Crees also demanded and generally got useful and quality trade goods, although their ability to affect the rates of exchange was limited primarily to pressure for stable prices and comparative pricing, when that was possible, among competing trading companies all setting prices for their traders in order to maximize profits.

The Crees also were able to shape the form and practice of the trade process itself, often not accepting a simple indebtedness created by traders' advances, and reshaping the relationships with traders into forms of partnership. To secure Cree efforts to trap more furs, and to try to tie Crees to their trading company, traders repeatedly adapted trade processes to Cree notions of reciprocity and enduring responsibilities. Traders often gave extensive gifts before trading began, sometimes up to half the value of the expected furs, and they gave special gifts and emblems of recognition to hunting leaders known as 'trading captains' (see Francis and Morantz I983). Traders living in isolated trading posts were often not maximizing profits but rather trying to please their bosses by doing a bit better than last year's returns (Salisbury 1976). The traders themselves were sometimes dependent on Crees for food supplies, and more often for love and companionship. When not effectively prohibited by the HBC, 'country wives' and families were common while traders were in the region. In these ways Cree forms of kinship, leadership and partnership structured much of the trade process, and resulted in forms of relationships, reciprocity and mutual aid that were clear and enduring, if not universal.

The relationships were not egalitarian, but amidst their continual changes there were some periods of enduring relationships of respect and mutual reciprocity. Cree recollections of the fur trade sometimes speak of it as a satisfying exchange, sometimes as excessively profitable for and insufficiently reciprocated by the companies. But it is almost always talked about in terms of mutual responsibilities and their abrogation or fulfilment. That is, the fur 
trade is not, whether it was a good or a bad thing at the period being discussed, a simple market relationship between producer and commercial enterprise or between a buyer and merchant.

From these stories of decades and centuries of fur trading Cree hunters know that commerce and coexistence on the land with 'Whitemen' (a Cree term) can be conducted on a different basis than that employed by HydroQuebec and forestry companies today. Their approaches demand respect and reciprocity whether they are dealing with logging foremen in the field discussing how close to cut the forest along a stream, or with corporate lawyers or professional foresters discussing policy and best-practice guidelines.

\section{Conserving beaver and co-governing territory}

Cree hunters' stories of relationships with representatives of governments are equally complex and ambiguous, but also embedded in mutual dependency and recognition. The first on-the-ground intervention of governments in the James Bay region occurred when beaver reserves were established by Quebec in the early I930s in response to the initiative of a concerned fur trader and his wife, working in dialogue with Cree hunters. Quebec was soon joined by Canada and the HBC, with the initial goal of restoring beaver populations depleted in the post-World War I boom years. The reserves excluded non-local trappers, who had been the main impetus for the depletion, as well as limiting Cree harvests until beaver populations recovered (Morantz 2002; Feit, in press). These initiatives had multiple origins, having been suggested in one form or another by fur traders, missionaries, anthropologists and Cree hunters from various communities.

When the time came actually to harvest beaver in the 1940s, the government claimed that its employees were exercising managerial authority over the beaver and the Crees. But the employees were confronted by their lack of knowledge of beaver dynamics and the distributions of beaver in the region. This made setting the quotas they envisioned difficult, as well as their decisions on how to allocate beaver harvest quotas to some Crees and not to others. To solve these problems government agents adopted and copied the Cree customary tenure system. Each hunting leader was paid to tally the number of active beaver lodges on his hunting territory, and to report them to government. The government then set the harvest quota and the hunting leaders were often left to allocate beaver taken on their territory to hunters whom they allowed to use their land. One government official described what was happening thus:

When it is borne in mind that the Tallyman is the head of the family; that each district is a family trapping ground; that ... all boundaries are laid out by the 
Indians themselves, it is apparent that we have not only adhered strictly to Indian custom but have actually improved on it since, through our Supervisor, we have maps of the districts and written records, which we can use to settle future disputes over trapping grounds. (Quoted in Morantz 2002: 167)

The claim that the beaver trapline system was an improvement obscured the fact that in practice it not only depended on the Cree hunting territory system; it left the Crees in charge of information and often allocation issues, and thereby left them to do what the hunting leader thought necessary on his land. The check the government had was when pelts were sold, but quota numbers were a function of Cree reports, and who killed beaver and where they were taken could be adjusted by Cree hunters, arranging among themselves who would do the selling or where they should report that the beaver had been caught.

The government beaver-reserve agents were more systematically dependent on the Crees than the reverse, although they claimed credit for the success of the scheme. Government officials and Cree hunters benefited from the plurality of practices and from the numerous ways they were interlinked. The Crees had exclusive use of their lands again as the government closed beaver reserves to other trappers; the appointment of hunting leaders as tallymen was taken by Crees as an acknowledgement by the government of the hunting tenure system, and it enhanced their legitimacy both within Cree society and by non-Cree. The government presented itself as having taken control of the governance of the lands and wildlife resources of the region, a claim that followed from the exercise of legislative authority, from the establishment of a new bureaucracy and from its control of public communications.

Under the beaver-reserve system, which lasted from the I93os up to the I970s, the Cree shared decisions about the use of the land for the first time, but on terms that were generally advantageous to themselves both in terms of decision-making and on-the-ground control of the land. Christine Saganash, the wife of Allen Saganash quoted above, said as part of her affidavit for the forestry case:

I remember so many years ago when Indian Affairs [agents] came to draw boundary lines [of the hunting territories for the Beaver Reserves]. Allen was already the tallyman. They gave him a badge to show he was a game warden. I still have that badge and carry it with me....

They must listen to us and respect us. We are the owners of the land. We are part of it. To cut our land is to destroy us and our way of life. (Affidavit of Christine (Jolly) Saganash, 22 July 1999)

Here government recognition not only acknowledges Cree governance; it affirms an expectation that lands would be used to protect a Cree way of life. The ambiguities over who was in control under the beaver-reserve system 
were heightened early in the I960s as government-promoted mining, commercial forestry and sport hunting and fishing increased dramatically. These problems created by new resource uses came to a head in I97 I when work began on the James Bay hydroelectric project.

\section{Choosing How to Fight Development Projects}

When a youthful Cree leadership emerged to lead a regional Cree opposition to the hydroelectric development in the early 1970 , the hunting elders were turned to for advice on what position to adopt vis-à-vis the governments. They set the crisis in history but also suggested perspectives that drew on their own authority over the land that was threatened by these development projects. Philip Awashish, one of the emerging Cree political leaders of the time, wrote that the elders were saying that the present pattern was

started by the arrival of the first white man into the area and still continues to this very day. Development is solely in the hands of people outside the region.... The region has been utilized almost exclusively by the Cree people who have no voice in the decision-making body which [is now] planning the development of resources in the area. (Awashish I972b, discussed in Feit 1985)

When asked what they saw as the goal of their opposition, Awashish reported that "most of the chiefs felt they would accept some form of hydro development under conditions that would be acceptable to the native people of the area. A negotiable development project would be the goal' (Awashish 1972a; see Feit 1985). The elders sought as a goal the experience of the sometimes respectful relationships of the past, but they now insisted that shared use of the land be explicitly negotiated and recognized.

The events put in motion by the ensuing court case and the negotiation of the JBNQA are described elsewhere in this book (see chapters 9 and Io by Coon Come and Craik). Cree hunters' visions of recent agreements are reflected in the 1999 affidavits where hunters express their mistrust and frustration at the failures and betrayals of negotiations and agreements, and with the sham consultative relationships governments and corporations established during this period of industrial resource developments (see, for example, Feit and Beaulieu 2001).

Yet Cree hunters and Cree leaders seek to find means of sharing the land, and continue to offer and insist on reciprocity with governments and developers. To comprehend this dual insistence on recognizing their Cree rights and also again establishing respectful relationships, we need to examine how the life projects of Crees are envisaged in the light of long local histories of relationships that extend transnationally to institutions of commerce and governance. We must also consider how their life projects are embedded in relations to their lands and the non-human beings on the land. 


\section{Their Words Cannot Be Trusted: Asserting Land as Agency}

As forestry expanded following the 1975 JBNQA, hunters like the late Noah Eagle tried throughout the I 980 os and I 990 s to communicate with forestry companies. When I talked to Noah two years after a first interview in which he reported to me that he had had talks with the companies about how to cut his land, he himself returned to the subject of forestry company practices because he wanted to report the results and wanted to make an invitation:

Another thing I want talk about is the log cutting... When they first started that business, they said they'd get the logs just in the bush not close to the river or creeks. But that is not true... They don't do what they said, just to cut down the trees from far in the bush. That's how everyone's ground is....

If anyone doesn't believe what we say, we could take them there to see or we'd take pictures of what we're talking about....

Then he described what was happening on the land:

Some Indians that hunt up north say they have a lot of moose there, where their ground is not yet damaged. I guess the moose just takes off and goes to where the land is good and plenty of their food there. It can't stay where the ground is damaged, it's the same way with all the other animals.

I don't know what will happen to us in the future, but right now we're okay, the way we're living. In the olden days I remember we didn't have any tea or sugar, all we had to drink was [the broth] from what we cooked, fish, rabbit and other game, we never had anything to make soup. And I think it's going to turn out that way pretty soon, by the way things look, in the past two years. (Noah Eagle, 8 May 1984; quoted in Feit and Beaulieu 200I)

Like those who gave affidavits more than a decade later, Noah is clear that he is dealing with people whose words cannot be trusted and who do not do what they say they will do. Yet he reaches out to seek recognition by forestry companies and his generalized listeners, and calls on them to recognize the dangers and act responsibly. His proposal is to invite his listeners to come and see what he has learned and seen on the land. ${ }^{7}$ Here Noah actively seeks the re-creation of mutual understanding. He has experienced that this cannot be achieved by yet another conversation with forestry company representatives. Rather, they need to come onto the land. I think that for Noah there is no use in a discursive contest over truth, or even a discursive effort to convince others through argument about whose truth should prevail. He avoids words and in their place issues invitations to enter a place more fully. But why? I think that he is inviting the forestry operators to come onto the land and learn from what the land has to teach. This suggestion requires a brief discussion of Cree ontology.

In the Cree hunters' view there is no fundamental separation in kind between the social world and the natural world, or between humans and 
nature, and the land is not a thing. The social world of the Crees extends beyond Cree society not just to other humans: the whole of the cosmos is understood as being a social world. That is, the whole of the Cree world is conceived of by most Cree hunters as comprising beings that are like persons. The world of Cree hunters is a society of non-human persons with wills, idiosyncrasies, intelligence and capacities of communication. Hunters emphasize that they know the non-human persons of the lands they hunt as individuals, not only as generalized categories of persons. They know the world through the relationships they know intimately.

Animals as persons are not soulless machines; animals are active agents. Animals are full of subjectivity, awareness and social relations, and they respond to and convey meaning through their actions. This is true of many 'natural' phenomena as well. Thus in the early I970s when I would ask about Chuetenshu, the powerful 'North Wind' person, I would get much more extended answers on cold and clear days associated with weather that arrived from the northwest. To talk extensively on warm days of the powerful and potentially dangerous wind person who brought cold and winter was potentially disrespectful and made many hunters uncomfortable. They did not like to talk in the absence, or 'behind the back', of so powerful a person. It could know what was said and might think it was not being referred to respectfully and could take offence. ${ }^{8}$ That did not prevent joking, or complaints, but in appropriate contexts as in all social relationships. The same was true of animals. They knew what was said of them, and they knew of the needs of hunters and their families. Because of these needs animals were often willing to give themselves to hunters so that humans could feed themselves, but in return they expected respect and reciprocity, a mutual caring for the well-being of each others' societies. Thus the hunt was both an exercise in the skill of the hunter and a result of the willing participation of the hunted animals. Animals left signs and indications of their presence and possible willingness to be killed for the hunter to find, signs that made the hunt possible and more reliable. Nevertheless, animals would also often unexpectedly escape when they were not ready to give themselves. This world of non-human persons has been described by numerous non-Crees who have encountered Cree hunters, from missionaries to fur traders to anthropologists (Hallowell I955; Preston 2002; Tanner I979; Feit 1994; and Scott 1996). This cosmology has repeatedly been shown to underlie an extensive system of traditional knowledge, hunting practice and effective game conservation (Feit 1994; Scott I996; Berkes 1999).

Thus, Noah does not invite his listeners into the bush to see an essentialized nature, or an objective fact, but to come on to the land in order to learn about relationships from those who live there. When moose numbers have declined it is because, as he indicates, many moose are choosing to 
move away from cutting areas both because their food is scarce and because they judge the land is not 'good' where there is forestry cutting. Inviting foresters to the bush would allow a subject-laden land to pass its own messages to viewers willing to learn about what is good or bad in this place after forestry operations have transformed it.

When Noah proposes to take people onto the land, we cannot dismiss this as either metaphorical or naive. As the work by Tim Ingold (2000) and Bruno Latour (1993) emphasizes, listeners need to avoid imposing the culture-nature separation on ontologies and epistemologies not founded on the assumptions that underlie the modern world-view that has developed since the sixteenth century. When we do that we treat them as just interpretations, whereas they are statements about what both is known and what is (see McGregor, Chapter 5 in this volume), made not by a knower separated from a nature that is passively known but from a human engaged in relations with other active persons. They are, we can say, statements from within non-modern life projects.

But what is the purpose of such an invitation, especially if one suspects the invitee is blind to the possibilities of learning from the animals on the land? An answer emerges from other Cree statements and responses to the forestry crisis.

\section{Life Projects and Relationships}

The views that I have suggested are implicit in Noah's invitation became clearer to me in exchanges among Crees over how to deal with governments and forestry companies. In a telephone conversation in the late r99os with a middle-aged Cree hunter about forestry cutting and the court action the Crees had initiated, I supported breaking off discussions with the forestry companies and accelerating legal action. He did not oppose court action, but he did oppose not talking at the same time to the companies. He said those Cree leaders who wanted to fight only in court were 'stupid', a strong word in his vocabulary, but one he thought I indirectly deserved. He asked rhetorically, 'Don't they' - those Cree leaders and myself - 'know that we cannot protect the land if we go around only blaming and accusing them?' He gave the example of declining moose numbers and the non-Cree sport hunt, saying we cannot simply blame the sport hunters. If we did that we could not respond effectively to the crisis because caring for the moose depends on working with the sport hunters and the government.

He claimed it was necessary to continue to seek relationships, even when they are not working, because only with such relationships can the animals and the land be effectively cared for and respected. To cut off relationships 
on an enduring basis in frustration would affect not only what can be in the future; it would affect the expression of relationships now. Cutting off communication denies the relationships one already has, and expresses a thoughtlessness and disrespect. His vision is not, however, modern in the sense that there is not any clear path to a defined objective or state: he does not offer a plan for establishing better or new relationships. He is committed to keeping relationships here and now, and by doing so to express here and now what is needed in the present and in visions of the future. Moreover, these relationships to animals and to others have implications for strategies of living.

\section{Animal Agency and Surviving}

These issues were expressed in the summer of 1998, when Waswanipi Cree hunters met to discuss possible responses to continuing forestry cutting on their lands. The leaders of the Cree communities had just accelerated their court case on forestry, and there was talk of blocking the provincial highway in protest against continued unregulated logging. The hunters heard from Cree negotiators about the modest changes that the forestry companies and the government of Quebec were proposing as their solutions. It was a meeting fraught with a sense of anxiety and frustration, although periodically relieved by humour. A middle-aged hunter and administrator said to Cree negotiators:

Go to the government and tell them about forestry. This is what is pushing wildlife out... How can we participate if they're not willing to participate with us? ... [logging companies] they're just going crazy and taking all the wood out and they're destroying the moose yards which are used in the winter time. They're destroying the mating grounds and they're destroying the playgrounds [of moose]. (Transcript, Waswanipi Cree Trappers Association Meeting, 26 August I 998)

It was a passionate speech, with a controlled but frustrated tone. The father of the speaker, himself an elder hunter, spoke later and he said that what had been said was true. But he went on to say:

The animals of this world love us, they can't leave us. I was told by my grandfather, who was a mean old man, ... if someone else kills your moose, it can happen that there will be more than what was killed. You showed love when you didn't say anything to the person who hunted on your territory, and that's how much love will be returned to you. (Transcript, Waswanipi Cree Trappers Association Meeting, 26 August 1998)

Although this sounds like a familiar story advising listeners to turn the other cheek, and the teller is an active Christian, the story is also embedded in 
Cree storytelling traditions and hunting practices. Crees do hunt and kill moose, and moose are persons who consent. Thus this is a story about complex relationships. It asserts that respectful and life-supporting relationships do continue, and indeed can continue, even in the midst of disrespectful and destructive practices, even by Cree.

Even so, it is not a metaphor; it is descriptive. The speaker is reminding his listeners that animals remain generous in the context of denials of respect and destruction of habitats by other humans. These moose are material persons. They are hunted, forestry reduces their food yards, mating success and play, and many moose chose to move away as a result. But moose do not cease to be, they are still being hunted, and they are still giving themselves to hunters both on lands affected by forestry, and in larger numbers on lands not yet affected. Moose that move away respond to the destructiveness of forestry, and those that stay show that some may survive in its midst.

The Cree ability to continue to receive animal gifts in the midst of extensive destruction caused by forestry is experientially undeniable, even if game numbers are reduced by the destruction. This both results from and confirms the continuing respectful relationships sustained by Cree hunters through this crisis. Animals here are social as well as very embodied teachers. They are active agents who help and are at the same time models of how to seek to continue to survive. The moose both move and stay amidst forestry, reflecting the dilemmas and suffering Cree face as the choices expressed in Cree hunting leaders' affidavits. The continuing survival and the continuing generosity of animals reassure Cree hunters of their own future in the midst of great destruction and uncertainty for both Cree and animals. To have to give up the land completely is unthinkable, and the moose confirm that it need not come to be. This story bespeaks a capacity both to survive abuse and suffering, and to continue to seek to change abusive relationships.

\section{Conclusions}

For Cree hunters and Cree political leaders, their opposition to development and at the same time their invitations to relationships are both essential to living here and now. ${ }^{y}$ The pursuit of relationships is not a request (waiting for others to act), a compliance (willing acceptance of failures of others to reciprocate), or an acquiescence to the control by others. It is an ongoing pursuit essential to maintaining the everyday lives and life projects of the Crees. It is in this knowledge that I think Noah Eagle offered his invitation.

Some readers will note with concern that seeking relationships with developers is a response that can be beneficial to state institutions and corporations. It is intended to be. This is not naive in the view of Cree hunting 
leaders. Recall the older hunter who defends the lessons of moose against too ready a dismissal by noting that his grandfather was 'a mean old man'. In doing so he highlights for his listeners that his grandfather did not act out of kindness when he did not confront those who killed moose on his hunting territory. He implies that this is the way things have to be done to benefit yourself as well as the moose. It is not just a morality but an ontology that motivates action here.

In seeking effective relationships within Cree life projects, the hunters reassert the power of their relationships to histories, lands, animals, to other places and peoples, and to the diversity of Crees and Cree communities. Contrary to what several analysts have suggested, this practice of inviting respectful relationships is not a sign of the need to compromise because the Crees have limited resources and power, although they do have limited means. It is not a turning to the moral because they cannot succeed in the political - they have had some significant successes (see Craik in this volume). It is not a sign of inconsistency in their commitment to their lands or a singular desire for monetary benefit. It is the means of re-creation of life projects and relationships for everyday living and survival in the midst of continuing destruction.

\section{Notes}

This chapter draws on the work of many Cree people and other scholars from whom I have drawn insights, including: Philip Awashish, Mario Blaser, Matthew Coon Come, Brian Craik, Paul Dixon, Sam Gull, Sr, Peter Harries-Jones, Peter Hutchins, Ted Moses, Matthew Ottereyes, Alan Penn and Colin Scott. Many others go unnamed. I also want to acknowledge financial support from the Social Sciences and Humanities Research Council of Canada, and the Arts Research Board of McMaster University.

I. The film-makers who caught part of this debate on video (some scenes look like they may have been re-enacted) themselves felt the contradiction enough to have to explain it to viewers, by stressing that offering an agreement at this time was part of a divide-and-rule tactic by Hydro-Quebec, which it was.

2. I use the term 'hunting leaders' for the generally elder Cree hunters who are the 'bosses' or 'tallymen' (see below) of family hunting territories. There are approximately 300 hunting territories in the region, and they range from about 200 to over 1,000 square miles. The territories are a key part of the Cree social and customary legal structures. Several elder and respected hunters or community leaders would also be included among this group of leaders as elders, although they do not have their own hunting territories. The designation is also intended to include spouses and women elders of the community.

3. I take the concept of life projects from Bruno Barras's chapter (3) and Mario Blaser's Introduction (Chapter 2) in this volume, but see also Escobar 1995: 212.

4. I am indebted to Wendy Russell for making this clear to me (see Russell, Chapter 8 in this volume). 
5. Similarly, in the very nature of the treaty-making process itself the government also acknowledges and acquiesces to some Cree sovereignty by acknowledging the relationship as one that requires treaty-making and agreements, and not just decrees and contracts.

6. The affidavits were prepared by legal counsel for the Cree in preparation for this court case. All were given verbally in Cree and were translated and transcribed into English.

7. He offers them photos if they cannot come because he recently worked with staff of the Grand Council of the Crees to photograph sites that exemplified the changes he was taking about.

8. For similar experiences, see Black 1977.

9. In 2002 the Cree signed a new agreement with Quebec which gave them a new role in forestry management, as well as consenting to new hydroelectric installations (see Craik in this volume).

\section{References}

Awashish, Philip (1972a) 'Report of Philip Awashish. Communications Worker Indians of Quebec Association on the James Bay Development Project. April Io-May 5, 1972', Huron Village, I I May 1972.

(I972b) 'Report of Philip Awashish Communications Worker. James Bay Development Project', Huron Village, 23 June 1972.

Berkes, Fikret (1999) Sacred Ecology: Traditional Ecological Knowledge and Resource Management, Philadelphia: Taylor \& Francis.

Black, Mary B. (1977) 'Ojibwe power belief systems', in R.D. Fogelson and R.M. Adams (eds), The Anthropology of Power, New York: Academic Press, pp. I4I-5I.

Escobar, Arturo (1995) Encountering Development: The Making and Unmaking of the Third World, Princeton: Princeton University Press.

Feit, Harvey A. (1985) 'Legitimation and autonomy in James Bay Cree responses to hydroelectric development', in Noel Dyck (ed.), Indigenous Peoples and the Nation State: Fourth World Politics in Canada, Australia, and Norway, St John's: Memorial University, Institute for Social and Economic Research, pp. 27-66.

- (1994) 'Hunting and the quest for power, the James Bay Cree and Whitemen in the twentieth century', in R.B. Morrison and C.R. Wilson (eds), Native Peoples: The Canadian Experience, and edn, Toronto: McClelland \& Stewart, pp. I 8 I-223.

- (2004) 'Contested identities of "Indians" and "Whitemen" at James Bay, or the power of reason, hybridity and agency', in T. Irimoto and T.Yamada (eds), Ethnicity and Identity in the North, Osaka: National Museum of Ethnology.

(in press) 'Co-governance and the uses of co-management', Anthropologica.

and Robert Beaulieu (200I) 'Voices from a disappearing forest: government, corporate, and Cree participatory forestry management practices', in C.H. Scott (ed.), Aboriginal Autonomy and Development in Northern Quebec and Labrador, Vancouver: University of British Columbia Press, pp. I I $9-48$.

Francis, Daniel and Toby Morantz (1983) Partners in Furs: $A$ History of the Fur Trade in Eastern James Bay, 1600-1870, Montreal: McGill-Queen's University Press.

Gupta, Akhil and James Ferguson (eds) (1999) Culture, Power, Place: Explorations in Critical Anthropology, Durham, NC: Duke University Press. 
Hallowell, A.I. (I955) Culture and Experience, Philadelphia: University of Pennsylvania Press.

Ingold, Tim (2000) 'Culture, nature, environment: steps to an ecology of life', in Perception of the Environment: Essays in Livelihood, Dwelling and Skill, London: Routledge, pp. I3-26.

Isacsson, Magnus (dir.) (I996) Power - One River, Two Nations, film, Montreal: Cineflix and the National Film Board of Canada.

LaRusic, Ignatius et al. (I979) Negotiating a Way of Life, Montreal: Indian Affairs and Northern Development Canada.

Latour, Bruno (1993) We Have Never Been Modern, Cambridge, MA: Harvard University Press.

Morantz, Toby (2002) The White Man's Gonna Getcha: The Colonial Challenge to the Crees in Quebec, Montreal: McGill-Queen's Press.

Preston, Richard (2002 [1975]) Cree Narrative, Montreal: McGill-Queen's Press.

Rousseau, Jean (200I) 'Les nouveaux défis des Cris de la Baie James à l'heure de la globalisation', Recherches amérindiennes au Québec, vol. 31, no. 3, pp. 73-82.

Salisbury, Richard F. (I976) 'Transactions or transactors: an economic anthropologist's view', in B. Kapferer (ed.) Transaction and Meaning, Philadelphia: Ishi, pp. $4 \mathbf{I - 5 9}$.

Scott, Colin H. ( $\left.\mathrm{I}^{8} \mathrm{8}_{3}\right)$ 'The semiotics of material life among the Wemindji Cree hunters', Ph.D. thesis, Department of Anthropology, McGill University.

- (1989) 'Ideology of reciprocity between James Bay Cree and the Whiteman state', in Peter Skalnik (ed.), Outwitting the State, New Brunswick, NJ: Transaction Press, pp. $8 \mathrm{I}-\mathrm{IO} 8$.

- (I996) 'Science for the west, myth for the rest?', in Laura Nader (ed.), Naked Science: Anthropological Inquiry into Boundaries, Power, and Knowledge, New York: Routledge, pp. $69-86$.

Tanner, A. (1979) Bringing Home Animals. Religious Ideology and Mode of Production of the Mistassini Cree Hunters, St John's: Memorial University, Institute of Social and Economic Research.

- (1999) 'Culture, social change, and Cree opposition to the James Bay Hydroelectric Project', in James F. Hornig (ed.), Social and Environmental Impacts of the James Bay Hydroelectric Project, Montreal: McGill-Queen's University Press, pp. I 2 I-40. 


\title{
In the Way of Development
}

\section{Indigenous Peoples, Life Projects and Globalization}

\author{
EDITED BY MARIO BLASER, \\ HARVEY A. FEIT AND GLENN MCRAE
}

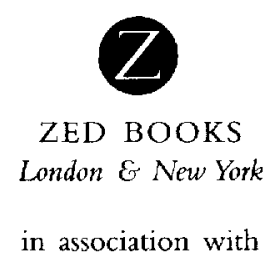

International Development Research Centre

Ottawa Cairo $\cdot$ Dakar $\cdot$ Montevideo $\cdot$ Nairobi $\cdot$ New Delhi $\cdot$ Singapore 
In the Way of Development was first published in 2004 by

Zed Books Ltd, 7 Cynthia Street, London NI 9JF, UK, and Room 400, I75 Fifth Avenue, New York, NY IOoIo, USA

in association with the International Development Research Centre, Box 8500 , Ottawa on, Canada kig 3 H9 info@idrc.ca/www.idrc.ca

www.zedbooks.co.uk

Editorial copyright (C) Mario Blaser, Harvey A. Feit and Glenn McRae, 2004 Copyright $\mathbb{C}$ individual contributors

The right of the contributors to be identified as the authors of this work have been asserted by them in accordance with the Copyright, Designs and Patents Act, 1988

Designed and typeset in Monotype Bembo by Illuminati, Grosmont Cover designed by Andrew Corbett Printed and bound by Gutenberg Press, Malta

Distributed in the USA exclusively by Palgrave Macmillan, a division of St Martin's Press, LLC, I75 Fifth Avenue, New York, NY 10010

All rights reserved

A catalogue record for this book is available from the British Library

Library of Congress Cataloging-in-Publication Data available

Zed ISBN I 84277 I92 2 (Hb)

Zed ISBN I 84277193 o (Pb)

IDRC ISBN I 552500047 